\title{
AN INNOVATIVE CONTINUOUS FLOW BNR-IC PROCESS FOR NUTRIENTS REMOVAL AND PHOSPHORUS RECOVERY FROM SYNTHETIC AND REAL DOMESTIC WASTEWATER
}

\author{
Haiming ZOU ${ }^{\mathrm{a}, \mathrm{b}}$, Xiwu LU \\ ${ }^{a}$ School of Resource and Environment, Anhui Science and Technology University, \\ Donghua Road, Fengyang 233100, PR China \\ ${ }^{b}$ School of Energy and Environment, Southeast University, Sipailou Road, Nanjing 210096, PR China
}

Submitted 28 Mar. 2015; accepted 23 Oct. 2015

\begin{abstract}
An innovative continuous flow process linking biological nutrients removal (BNR) with induced crystallization (IC) was used to remove nutrients and recover phosphorus (P) from synthetic and real domestic wastewater. The results showed that a good nutrients removal performance was found regardless of feeding solutions. $\mathrm{P}$ recovery efficiency from synthetic wastewater was $70.2 \%$ slightly less than that from real domestic sewage (74.2\%). Importantly, P recovery can effectively enhance the subsequent biological P removal. Polymerase chain reaction-denaturing gradient gel electrophoresis (PCR-DGGE) analysis displayed an obvious shift in microbial community structure when switching feeding synthetic solution to real wastewater. A total of 13 bands were detected in sludge samples using synthetic and real domestic sewage, affiliated with 8 phyla or classes domain Bacteria (Alphaproteobacteria, Betaproteobacteria, Gammaproteobacteria, Flavobacteria, Actinobacteria, Sphingobacteria, Epsilonproteobacteria and Chlorobia). The results obtained here suggest that the continuous flow BNR-IC process is feasible for nutrients removal and $\mathrm{P}$ recovery from domestic sewage and is a promising technology for wastewater treatment combined with recycling of $\mathrm{P}$ elements.
\end{abstract}

Keywords: nutrients removal, phosphorus recovery, induced crystallization, denitrifying polyphosphate accumulating organisms, denaturing gradient gel electrophoresis.

\section{Introduction}

Phosphorus $(\mathrm{P})$ is one of critical elements required for biomass growth. According to the Liebig law of the minimum, the biomass (experience formula: $\mathrm{C}_{106} \mathrm{H}_{263} \mathrm{O}_{110} \mathrm{~N}_{16} \mathrm{P}$ ) (Moheimani et al. 2013) growth productivity is mainly determined by the supply of $\mathrm{P}$ in water bodies. Nowadays, eutrophication or algae blooming of water bodies is an increasing pollution problem worldwide due to the excessive discharge of P loading into lakes, rivers or reservoirs. Except Oceania and Africa, about $50 \%$ of all reservoirs and lakes are subject to eutrophication in all continents (Sengupta, Pandit 2011). In China, lakes of Dianchi, Chaohu and Taihu are eutrophic. Currently, eutrophication is of particular concern in water bodies, since it results in the water environmental degradation, threatens the survival of aquatic species and affects the safety of drinking water. More than $0.02 \mathrm{mg} / \mathrm{L}$ of $\mathrm{P}$ in lakes can cause eutrophication (Seviour et al. 2006). In domestic sewage, the fluctuation of $\mathrm{P}$ concentration ranges from $3 \mathrm{mg} / \mathrm{L}$ to $10 \mathrm{mg} / \mathrm{L}$, often requiring mandatory removal before discharge into water bodies. Consequently, a strict P limit in effluents from municipal wastewater treatment plants (WWTP) was set in legislation by governments in the world. For instance, there is a compulsory requirement of TP concentration in effluents from WWTP to be less than $0.1 \mathrm{mg} / \mathrm{L}$ in North America and $0.5 \mathrm{mg} / \mathrm{L}$ in China (Zou et al. 2014a). Methods for P removal from domestic wastewater are commonly biological, physical or chemical. Compared with chemical or physical methods, recent advances in enhance biological phosphorus removal (EBPR) have demonstrated that it was regards as an effective and economic technology for P removal from domestic wastewater (Ong et al. 2014; Yang et al. 2013; Zhang et al. 2013).

Today, another a notable aspect of phosphorus problem is that $\mathrm{P}$ is a non-renewable mineral resource, mostly obtained from phosphate rock. If current exploitation rate of phosphate rock is continued it is predicted to run out in next 50 years (Gilbert 2009). Thus, it is very urgent to reuse and recycle $\mathrm{P}$ from human activities, i.e. phosphorus

Corresponding author: Haiming Zou

E-mail: hmzou@126.com 
recovery, which has drawn considerable attention in recent years (Acelas et al. 2014; Hutnik et al. 2013; Qiu, Ting 2014). It is noteworthy that about $3 \sim 10 \mathrm{mg} / \mathrm{L}$ of $\mathrm{P}$ in domestic sewage may provide a valuable potential market for P recovery. Current technology for P recovery from domestic wastewater mainly adopted chemical precipitation and the commonly used processes were the two types of struvite $\left(\mathrm{NH}_{4} \mathrm{MgPO}_{4}\right.$, MAP) (Cusick, Logan 2012; Ichihashi, Hirooka 2012) and hydroxylapatite $\left(\mathrm{Ca}_{10}\left(\mathrm{PO}_{4}\right)_{6}(\mathrm{OH})_{2}, \mathrm{HAP}\right)$ (Zou et al. 2014b), which were regarded as a slow release fertilizer (Yetilmezsoy, SapciZengin 2009). In addition to, $\mathrm{Al}$ and $\mathrm{Fe}$ ions also have a great affinity for P binding (Westholm 2006). Since phosphate fertilizer accounted for about $80 \%$ of used phosphate rock in the world (Guney et al. 2008), MAP or HAP (similar to fertilizer component) precipitation should be preferred to recover $\mathrm{P}$ element from solution.

The discussion above shows that both natural phosphate rock diminution and pollution due to $\mathrm{P}$ excessive discharge should be solved quickly. This may lead to a new research on P removal coupled with P recovery from domestic sewage to meet the effluent standards and recycle phosphate rock. Recently, several attempts have been conducted to develop new combination process that remove nutrients and recover P (Ichihashi, Hirooka 2012; Song et al. 2014; Yuan et al. 2012), in particular to investigate the $\mathrm{P}$ recovery from excess sludge. However, most of those reported on the combination process about biological nutrients removal coupled with chemical precipitation. Of them, a well-known wastewater treatment process linking nutrients removal with P recovery is the Phostrip (Yuan et al. 2012), adopting biological nutrients removal combined with chemical precipitation, where the $P$ in supernatant generated from excess sludge digestion was recovered by MAP or HAP precipitation. The disadvantages of the process are obvious: (1) increasing cost in excess sludge digestion system; (2) lower P recovery efficiency due to recover P only from excess sludge; (3) chemical precipitation product (such as MAP or HAP) is not directly used to industrial or agricultural activities owe to contain high moisture or impurity content, where the induced crystallization technology may be a preferable alternative to recovery P from solution.

More recently, our research team developed an innovative process of biological nutrients removal (BNR) coupled with induced crystallization (IC), referred herein to as "BNR-IC", responsible for P removal with P recovery (Shi et al. 2012; Zou et al. 2014a). The process overcame disadvantages of conventional process mentioned above. Although good nutrients removal and $\mathrm{P}$ recovery performances were found in our previous results via serial batch experiments (Zou et al. 2014c), the behavior of BNR-IC operation in continuous flow is not still unclear, especially for treatment real domestic wastewater rather than synthetic wastewater. Most studies on domestic wastewater treatment were nowadays performed by feeding the artificial wastewater. However, the component of real domestic sewage is more extensive and complex than that of synthetic wastewater, thus resulting in the infeasibility of application of results obtained from synthetic wastewater treatment to practice. Consistently, there is a large discrepancy in results obtained from between batch tests and continuous flow experiments. For this, in the innovative BNR-IC process, real domestic sewage treatment operated by continuous flow has to be performed in the further study.

Therefore, the aim of this study was to investigate whether stable and high nutrients removal and P recovery from synthetic and real domestic wastewater can be obtained in the continuous flow BNR-IC process. The carbon, nitrogen and phosphorus content in the influent and effluent were monitored. Furthermore, the differences of microbial community structure between feeding synthetic wastewater and feeding real domestic sewage were also compared by microbial analysis. The results obtained from here may serve as a good suggestion for application of the novel BNR-IC process to practice.

\section{Materials and methods}

\subsection{Experimental set-up and operation}

The BNR-IC process (Fig. 1, left) proposed here consisted of biological nutrients removal (BNR) system and induced crystallization (IC) P recovery column (Fig. 1, right). The BNR system is an anaerobic/anoxic/aerobic process with double-sludge, in which denitrifying polyphosphate accumulating organisms (DPAO) performed denitrifying simultaneous nitrogen and phosphorus removal. The IC column was comprised of crystallization, buffer and settling zones, which was proposed and described by our

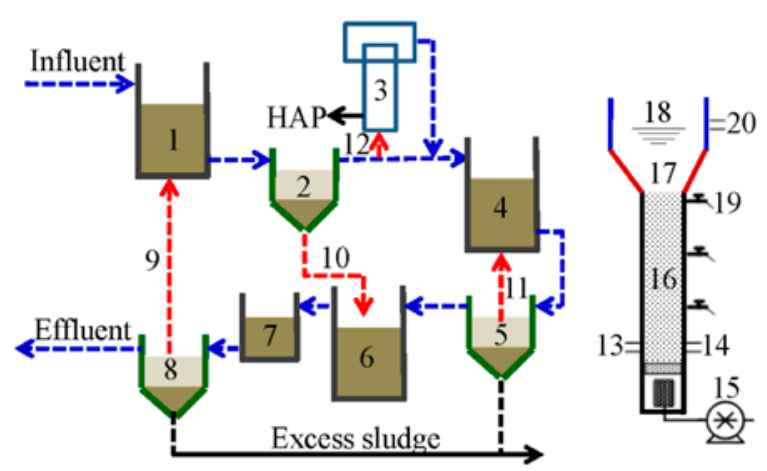

Fig. 1. Schematic diagram of the BNR-IC process.1- anaerobic tank; 2- settling tank; 3- IC column; 4- nitrification tank; 5settling tank; 6- anoxic tank; 7- post-aeration tank; 8- settling tank; 9- sludge return; 10- sludge bypass return; 11- sludge return; 12- later flow; 13- influent of P-rich solution; 14feeding $\mathrm{CaCl} 2$ solution; 15- aeration; 16- IC reaction zone; 17- buffer zone; 18 - settling zone; 19 - sample point; 20 effluent 
research group (Zou et al. 2014b). In the BNR-IC process, the P-rich supernatant in settling tank 2 was partly introduced into IC column to recover $\mathrm{P}$ and the sludge from settling tank 2 was led into anoxic tank 6 for denitrifying simultaneous nitrogen and phosphorus removal. The postaeration tank enhanced the final effluent quality.

Synthetic wastewater and real domestic sewage were used and compared in this study. The influent flow was $18 \mathrm{~L} / \mathrm{d}$, and the bypass sludge flow (10), return sludge flow $(5,8)$ were all $7.2 \mathrm{~L} / \mathrm{d}$. The later flow ratio $(12)$ was $6.3 \mathrm{~L} / \mathrm{d}$, i.e. $35 \%$ of supernatant from settling tank 2 introduced into the IC column, where $4.5 \mathrm{mM} \mathrm{CaCl}_{2}$ solution was led into the IC column with the flow rate of $0.63 \mathrm{~L} / \mathrm{d}$. The aeration flow was $90 \mathrm{~L} / \mathrm{h}$ both in aerobic tank and post-aeration tank, resulting in the dissolve oxygen (DO) high than $2 \mathrm{mg} / \mathrm{L}$ and that was $270 \mathrm{~L} / \mathrm{h}$ in IC column, for $\mathrm{CO}_{2}$ stripping and fluidization of seed crystals (calcite used here).

\subsection{Synthetic and real domestic wastewater}

The synthetic domestic wastewater contained carbon, nitrogen and phosphorus in the typical species of real domestic sewage, specific composition detailed in Table 1. COD, $\mathrm{NH}_{4}^{+}-\mathrm{N}, \mathrm{TN}$ and TP concentrations in the influent were 239.2 259.5 mg/L, 38.2 41.8 mg/L, 39.6 43.8 mg/L and $8.72 \sim 11.40 \mathrm{mg} / \mathrm{L}$, respectively. Real domestic wastewater was collected from the Southeast University, Wuxi, China and its main characteristics were described in Table 2.

Table 1. Composition of synthetic wastewater used in this study.

\begin{tabular}{lclc}
\hline $\begin{array}{c}\text { Composition } \\
\text { of feeds }\end{array}$ & $\begin{array}{c}\text { Concen- } \\
\text { tration, g/L }\end{array}$ & $\begin{array}{c}\text { Composition } \\
\text { of nutrient } \\
\text { solution }\end{array}$ & $\begin{array}{c}\text { Concen- } \\
\text { tration, g/L }\end{array}$ \\
\hline $\mathrm{CH}_{3} \mathrm{COONa}$ & 0.322 & $\mathrm{FeCl}_{3} \cdot 6 \mathrm{H}_{2} \mathrm{O}$ & 1.50 \\
$\mathrm{KH}_{2} \mathrm{PO}_{4}$ & 0.044 & $\mathrm{H}_{3} \mathrm{BO}_{3}$ & 0.15 \\
$\left(\mathrm{NH}_{4}\right)_{2} \mathrm{SO}_{4}$ & 0.047 & $\mathrm{CuSO}_{4} \cdot 5 \mathrm{H}_{2} \mathrm{O}$ & 0.03 \\
$\mathrm{CaCl}_{2}$ & 0.005 & $\mathrm{KI}$ & 0.18 \\
$\mathrm{MgSO}_{4} \cdot 7 \mathrm{H}_{2} \mathrm{O}$ & 0.05 & $\mathrm{MnCl}_{2} \cdot 4 \mathrm{H}_{2} \mathrm{O}$ & 0.12 \\
$\mathrm{Nutrient}_{\text {solution }}$ & $0.30 \mathrm{~mL} / \mathrm{L}$ & $\mathrm{Na}_{2} \mathrm{MoO}_{4} \cdot 2 \mathrm{H}_{2} \mathrm{O}$ & 0.06 \\
& & $\mathrm{ZnSO}_{4} \cdot 7 \mathrm{H}_{2} \mathrm{O}$ & 0.12 \\
& & $\mathrm{CoCl}_{2} \cdot 6 \mathrm{H}_{2} \mathrm{O}$ & 0.15 \\
& & $\mathrm{EDTA}$ & 10.00
\end{tabular}

Table 2. Characteristics of real domestic sewage used in this study.

\begin{tabular}{lcc}
\hline \multicolumn{1}{c}{ Contents } & Range & Average \\
\hline $\mathrm{COD}(\mathrm{mg} / \mathrm{L})$ & $153.71-223.63$ & $188.94 \pm 16.26$ \\
$\mathrm{NH}_{4}{ }^{+} \mathrm{N}(\mathrm{mg} / \mathrm{L})$ & $38.50-55.72$ & $48.26 \pm 3.85$ \\
$\mathrm{TN}(\mathrm{mg} / \mathrm{L})$ & $50.35-67.28$ & $60.01 \pm 3.85$ \\
$\mathrm{TP}(\mathrm{mg} / \mathrm{L})$ & $3.76-6.43$ & $5.03 \pm 0.67$ \\
$\mathrm{pH}$ & $7.08-7.69$ & $7.36 \pm 0.19$ \\
\hline
\end{tabular}

\subsection{Experimental procedure}

Before the continuous flow experiments, the two types of activated sludge responsible for phosphorus removal and nitrification have been cultivated in batch tests (Haiming et al. 2014), i.e. the start-up of the BNR-IC system. And then, the operating in continuous flow was conducted and divided into two main phases described as follows: (1) from day 0 to day 30 , the BNR-IC was operated by feeding synthetic wastewater; (2) at day 31 , the real domestic sewage treatment was started for 60 days. During this period, the mixed liquid suspended solid (MLSS) were 3400 3600 mg/L both in anaerobic and anoxic tank and that was 3000 3200 mg/L in nitrification tank. The solids retention times (SRTs) of nitrification sludge and phosphorus removal sludge were 12 and 16 days, respectively.

\subsection{Analytical methods}

$50 \mathrm{~mL}$ of samples collected (once a day) from influent and effluent of the BNR-IC were filtered through 0.45-micron membrane filters using a microfiltration apparatus before analysis. COD and MLSS were monitored in accordance with the standard methods (APHA, 2005). TP, $\mathrm{NH}_{4}^{+}-\mathrm{N}$ and $\mathrm{TN}$ were performed by using segmented flow analysis (AutoAnalyzer3, SEAL, UK). DO was determined by a DO meter analyzer (YSI DO200, USA) and pH was assessed by a pH meter analyzer (YSI pH100, USA). Statistical treatment (arithmetic mean and standard deviations) of experimental data was done using ORIGIN software (Microcal Software, Northhampton, MA).

Sludge samples $(100 \mathrm{~mL})$ were collected at day 30 and 90 for Polymerase Chain Reaction-Denaturing Gradient Gel Electrophoresis (PCR-DGGE) analysis, described in our previous report (Zou et al. 2014c), mainly including sludge sample pretreatment, total DNA extraction, PCR amplification, DGGE analysis and sequencing of PCRamplified 16S ribosomal (r) DNA.

\section{Results and discussion}

\subsection{Removal of nutrients from synthetic and real domestic wastewater}

Figures 2 and 3 and Table 3 show the carbon, nitrogen and phosphorus concentrations of influent and effluent in the BNR-IC process, using synthetic and real domestic wastewater. In the final periods of operation, a similar nutrients removal behavior was found in the system at day 30 and day 90, respectively. At the stable state, $\mathrm{COD}, \mathrm{NH}_{4}^{+}-$ $\mathrm{N}, \mathrm{TN}$ and TP concentrations of effluent remained at a low level and were on average $18.75 \pm 3.50 \mathrm{mg} / \mathrm{L}, 5.64 \pm 0.26$ $\mathrm{mg} / \mathrm{L}, 8.99 \pm 0.97 \mathrm{mg} / \mathrm{L}$ and $0.42 \pm 0.03 \mathrm{mg} / \mathrm{L}$ in synthetic wastewater and $25.35 \pm 9.72 \mathrm{mg} / \mathrm{L}, 4.35 \pm 0.52 \mathrm{mg} / \mathrm{L}$, $11.89 \pm 1.54 \mathrm{mg} / \mathrm{L}$ and $0.46 \pm 0.02 \mathrm{mg} / \mathrm{L}$ in real domestic sewage, respectively, meeting the discharge standard of 

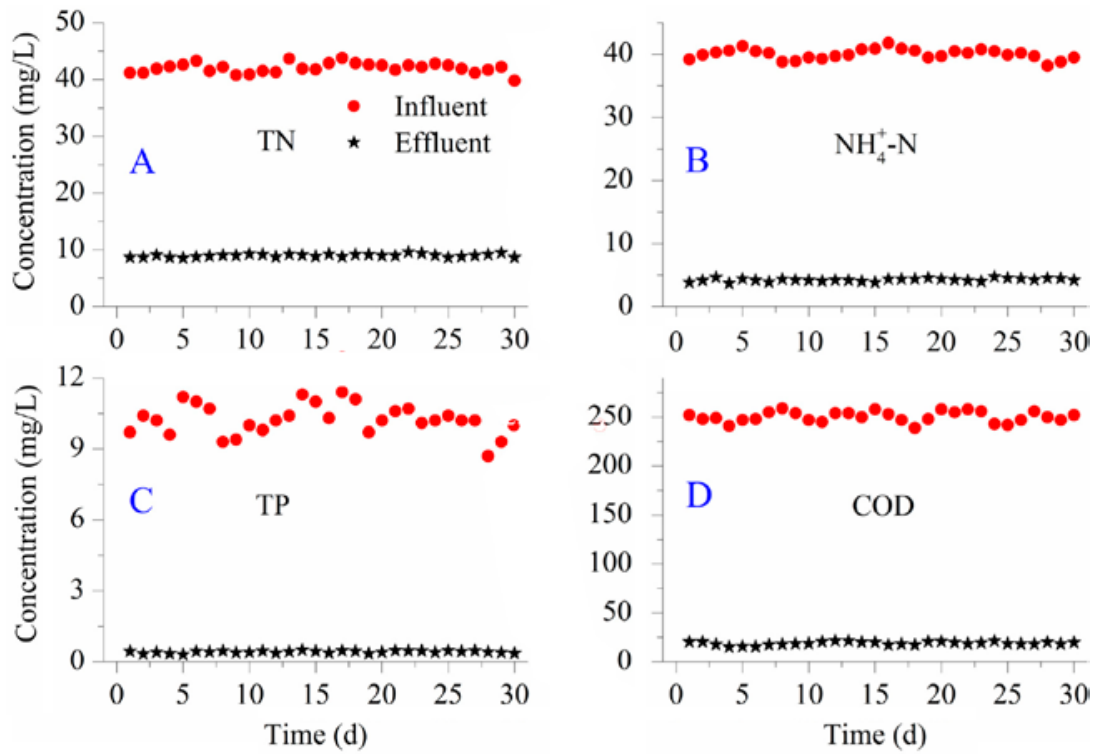

Fig. 2. Variations of COD, NH4-N, TN and TP in the influent and effluent and removal efficiency during synthetic wastewater treatment
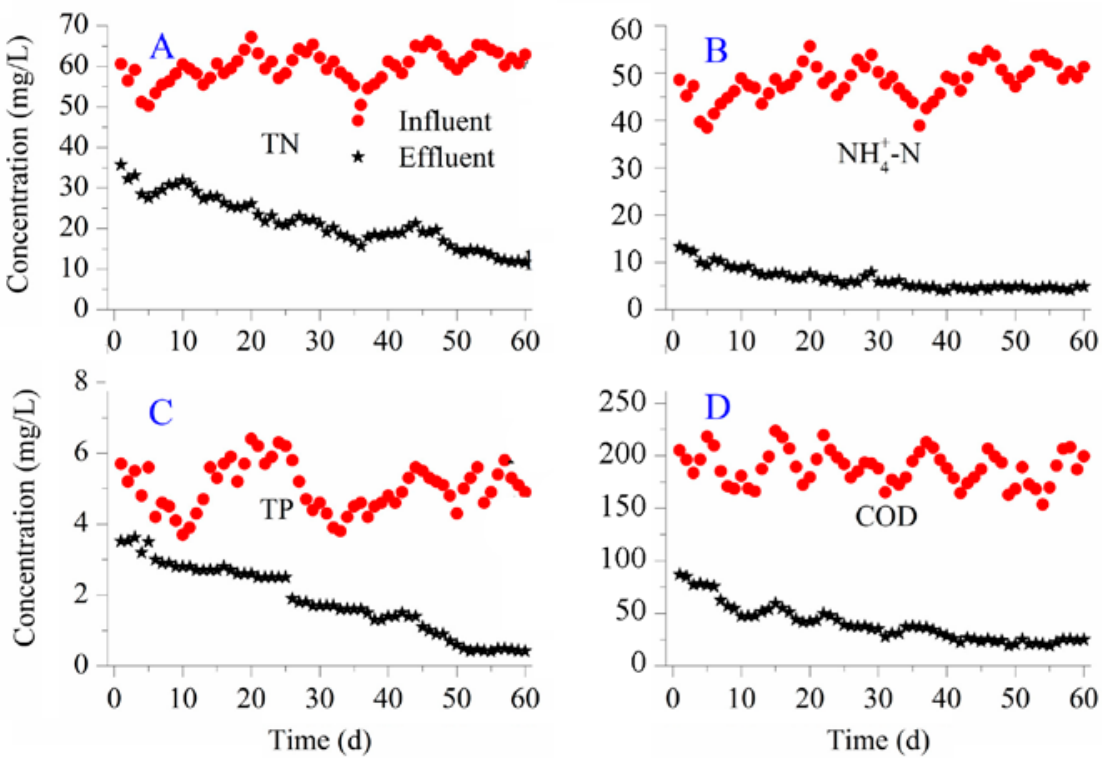

Fig. 3. Variations of COD, NH4-N, TN and TP in the influent and effluent and removal efficiency during real domestic sewage treatment

Table 3. Averaged concentrations of COD, $\mathrm{NH}_{4}-\mathrm{N}, \mathrm{TN}$ and $\mathrm{TP}$ in the influent and effluent and those averaged removal efficiencies when synthetic or real domestic wastewater

\begin{tabular}{lccrrrr}
\hline \multirow{2}{*}{$\begin{array}{c}\text { Contents } \\
(\mathrm{mg} / \mathrm{L})\end{array}$} & \multicolumn{3}{c}{ Synthetic domestic wastewater } & \multicolumn{3}{c}{ Real domestic wastewater } \\
\cline { 2 - 7 } & \multicolumn{1}{c}{ Influent } & Effluent & $\mathrm{RE} \mathrm{( \% )}$ & Influent & Effluent & RE (\%) \\
\hline $\mathrm{COD}$ & $250.00 \pm 2.30$ & $18.75 \pm 3.50$ & $92.51 \pm 1.41$ & $188.94 \pm 16.26$ & $25.35 \pm 9.72$ & $87.33 \pm 2.05$ \\
$\mathrm{NH}_{4}{ }^{+}-\mathrm{N}$ & $40.00 \pm 0.82$ & $5.64 \pm 0.26$ & $85.93 \pm 1.28$ & $48.26 \pm 3.85$ & $4.35 \pm 0.52$ & $90.21 \pm 1.08$ \\
$\mathrm{TN}$ & $42.00 \pm 1.21$ & $8.99 \pm 0.97$ & $78.62 \pm 1.36$ & $60.01 \pm 3.85$ & $11.89 \pm 1.54$ & $79.66 \pm 2.09$ \\
$\mathrm{TP}$ & $10.00 \pm 0.46$ & $0.42 \pm 0.03$ & $95.20 \pm 0.99$ & $5.03 \pm 0.67$ & $0.46 \pm 0.02$ & $90.67 \pm 1.18$ \\
\hline
\end{tabular}


municipal domestic sewage treatment (GB 18918-2012) formulated by Chinese government. The low $\mathrm{P}$ content in effluent was attributed to the joint action of induced crystallization $\mathrm{P}$ recovery and biological phosphorus removal by DPAO. In conventional wastewater treatment process, $P$ content of effluent was hard to meet the stringent discharge standard due to the lack of carbon in real domestic sewage, i.e. low $\mathrm{C} / \mathrm{N}$. However, in the BNR-IC system, although the $\mathrm{C} / \mathrm{N}$ ratios $(5.9 \pm 0.8$ in synthetic wastewater and $3.2 \pm 0.3$ in real domestic sewage) were still low, P concentrations of effluent were both less than $0.5 \mathrm{mg} / \mathrm{L}$, this suggesting that $\mathrm{P}$ recovery effectively enhance the subsequent biological P removal by DPAO due to the decrease at $\mathrm{P}$ loading in solution. Another reason may be that DPAO mainly performed the denitrifying simultaneous nitrogen and phosphorus removal in anoxic tank, considerably saving the consumption of carbon source ( $\mathrm{Lv}$ et al. 2015).

During the treatment of synthetic wastewater (30 days), the COD, $\mathrm{NH}_{4}{ }^{+} \mathrm{N}, \mathrm{TN}$ and TP removal performances (Fig. 2) were still constant stable and more than $90 \%$ of $\mathrm{C}$ and $\mathrm{P}$ and around $80 \%$ of $\mathrm{N}$ were removed from synthetic solution, where those removal efficiencies were $92.51 \pm 1.41 \%, 85.93 \pm 1.28 \%, 78.62 \pm 1.36 \%$ and $95.20 \pm 0.99 \%$, respectively. This is mainly due to the fact that two types of activated sludge responsible for $\mathrm{P}$ removal and nitrification were cultured by feeding synthetic wastewater.

For real domestic sewage treatment, as was expected, the nutrients removal efficiencies were extremely low and fluctuant during the beginning period (Fig. 3). With the operation in continuous flow, carbon, nitrogen and phosphorus concentrations in effluent decreased gradually and those removal efficiencies finally remained stable and high after approximately 55 days. The $\mathrm{COD}, \mathrm{NH}_{4}^{+}-\mathrm{N}, \mathrm{TN}$ and TP removal efficiencies were $87.33 \pm 2.05 \%, 90.21 \pm 1.08 \%$, $79.66 \pm 2.09 \%$ and $90.67 \pm 1.18 \%$, respectively, in which, compared with synthetic wastewater treatment, both COD

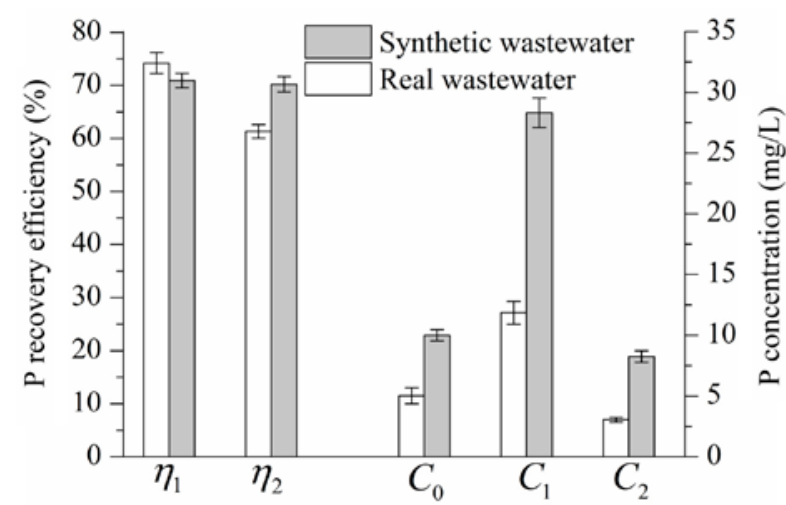

Fig. 4. P concentrations in the influent and effluent of IC column and its recovery efficiencies from synthetic and real wastewater and $\mathrm{P}$ removal rates were slightly lower while the $\mathrm{N}$ removals including $\mathrm{NH}_{4}^{+}-\mathrm{N}$ and TN were somewhat higher. The lower COD and P removal performances probably result from a decrease in DPAO when treating real domestic sewage. A high content of microorganisms responsible for only denitrifying rather than denitrifying simultaneous nitrogen and phosphorus in domestic wastewater may lead to the high nitrogen removal performance.

\subsection{Recovery of phosphorus from synthetic and real domestic wastewater}

This study introduces an innovative technology and approach to recover $P$ from effluent of anaerobic phase by induced crystallization in the BNR-IC system. The P removal efficiency in IC column and recovery efficiency per liter of wastewater were calculated with the following equations (1) and (2), respectively.

$$
\begin{gathered}
\eta_{1}=\frac{C_{1}-C_{2}}{C_{1}} \times 100 \% ; \\
\eta_{2}=\frac{0.35\left(C_{1}-C_{2}\right)}{C_{0}} \times 100 \%,
\end{gathered}
$$

where: $C_{0}$ is the $\mathrm{P}$ concentration in synthetic or real domestic wastewater $(\mathrm{mg} / \mathrm{L}) ; C_{1}$ is the $\mathrm{P}$ concentration in the effluent of settling tank $2(\mathrm{mg} / \mathrm{L}) ; C_{2}$ is the P concentration of IC column effluent $(\mathrm{mg} / \mathrm{L}) ; 0.35$ represents the later flow ratio.

Figure 4 presents the influent and effluent characteristics including $C_{0}, C_{1}$ and $C_{2}, \mathrm{P}$ removal efficiency in IC column $\left(\eta_{1}\right)$ and P recovery efficiency in BNR-IC $\left(\eta_{2}\right)$, calculated according to Eqs. (1) and (2), during treatment of synthetic and real wastewater.

As can be seen from Figure 4, the thickener P-rich supernatant was obtained in anaerobic tank $\left(C_{1}\right)$ and partly sent to the induced crystallization column for recovering P. During the crystallization process, P content in the solutions fed to the IC column gradually decreased ranging from 28.31 to $8.35 \mathrm{mg} / \mathrm{L}$ for synthetic wastewater and 11.85 to $3.06 \mathrm{mg} / \mathrm{L}$ for real domestic wastewater, displaying a good $\mathrm{P}$ removal performance during induced crystallization process. A specific $\mathrm{P}$ concentration of $10 \mathrm{mg} / \mathrm{L}$ in the synthetic wastewater was assumed, with a resulting $70.2 \%$ of $\mathrm{P}$ recovery efficiency. Nevertheless, when $\mathrm{P}$ concentration was $5.03 \mathrm{mg} / \mathrm{L}$ in real domestic sewage, $74.2 \%$ of $\mathrm{P}$ recovery efficiency was found. This suggests that lower $\mathrm{P}$ concentration in wastewater may lead to a higher P recovery efficiency.

\subsection{Change of microbial community structure with feeding synthetic and real domestic wastewater}

A total of 13 bands with strong intensity were observed in the two DGGE band patterns, as given in Figure 5. Although there was no significant difference on nutrients 

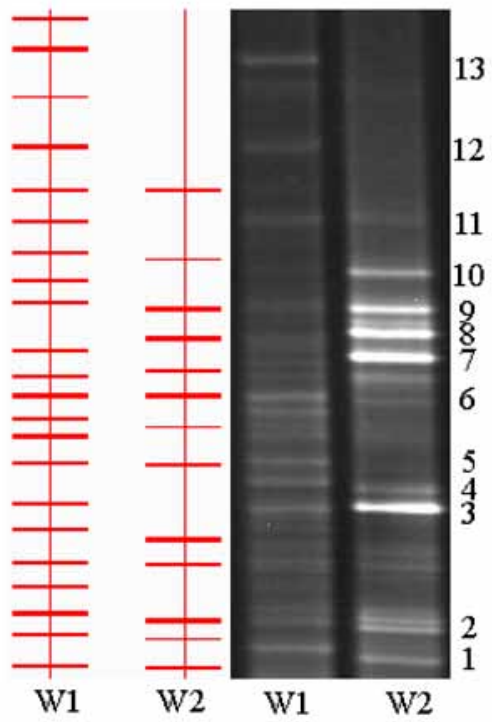

Fig. 5. DGGE fingerprint of 16Sr DNA fragments (right) and lanes comparison (left). W1-real domestic wastewater; W2synthetic domestic wastewater

removal efficiencies between using synthetic and real domestic wastewater, sludge sample with real domestic sewage displayed a larger diversity of microbial community structure than that with synthetic wastewater. This suggests that influent composition appears to have an influence on the microbial populations, which was consistent with the report (Boelee et al. 2011). This may be due to more complex compositions in real domestic sewage than that in synthetic wastewater, probably supporting other bacterial growth. Moreover, real domestic wastewater may be introduced in various microorganisms when passing through sewage conduits (Thai et al. 2014). Here, Dice coefficient, comparing the similarities of DGGE fingerprints from different feeding, was 0.42 , also suggesting a large shift of microbial community structure when switching feeding synthetic wastewater to real domestic wastewater.

Of these 13 bands, 6 (band 1, 2, 3, 4, 6 and 11) bands were common to both the synthetic wastewater sludge and real domestic sewage sludge. The rest, 3 (band 5, 12 and 13) bands were only found in real domestic sewage sludge and another $4(7,8,9$ and 10$)$ only presented in synthetic wastewater sludge. As can be seen in Table 4 and Figure 5, 13 distinct DGGE bands revealed that microbial species were affiliated with 8 phyla or classes domain Bacteria: Alphaproteobacteria, Betaproteobacteria, Gammaproteobacteria, Flavobacteria, Actinobacteria, Sphingobacteria, Epsilonproteobacteria and Chlorobia.

16S rRNA fragments of bands 3, 7, 8, 9, 10 and 11 belong to genus Flavobacterium spp., Pseudomonas spp., Terrimonas spp., Thermomonas spp., Simplicispira spp. and Arcobacter spp. Of them, Pseudomonas spp., Terrimonas spp. and Thermomonas spp. with high content in the
Table 4. NCBI BLAST search results of sequences from DGGE bands.

\begin{tabular}{|c|c|c|c|}
\hline Band & $\begin{array}{l}\text { Closest } \\
\text { match }\end{array}$ & $\begin{array}{c}\text { Similarity } \\
\%\end{array}$ & $\begin{array}{l}\text { Phylogenetic } \\
\text { affiliation }\end{array}$ \\
\hline 1 & $\begin{array}{l}\text { Acinetobacter } \\
\text { spp. }\end{array}$ & 98 & Gammaproteobacteria \\
\hline 2 & $\begin{array}{l}\text { Rhodocyclus } \\
\text { spp. }\end{array}$ & 96 & Betaproteobacteria \\
\hline 3 & $\begin{array}{l}\text { Flavobacterium } \\
\text { spp. }\end{array}$ & 100 & Flavobacteria \\
\hline 4 & $\begin{array}{l}\text { Brachymonas } \\
\text { spp. }\end{array}$ & 98 & Betaproteobacteria \\
\hline 5 & $\begin{array}{l}\text { Tetrasphaera } \\
\text { spp. }\end{array}$ & 99 & Actinobacteria \\
\hline 6 & $\begin{array}{l}\text { Dechlorosoma } \\
\text { spp. }\end{array}$ & 95 & Betaproteobacteria \\
\hline 7 & $\begin{array}{l}\text { Pseudomonas } \\
\text { spp. }\end{array}$ & 100 & Gammaproteobacteria \\
\hline 8 & Terrimonas spp. & 100 & Sphingobacteria \\
\hline 9 & $\begin{array}{l}\text { Thermomonas } \\
\text { spp. }\end{array}$ & 100 & Gammaproteobacteria \\
\hline 10 & $\begin{array}{l}\text { Simplicispira } \\
\text { spp. }\end{array}$ & 100 & Betaproteobacteria \\
\hline 11 & Arcobacter spp. & 100 & Epsilonproteobacteria \\
\hline 12 & $\begin{array}{l}\text { Chlorobaculum } \\
\text { spp. }\end{array}$ & 87 & Chlorobia \\
\hline 13 & $\begin{array}{l}\text { Methylocystis } \\
\text { spp. }\end{array}$ & 98 & Alphaproteobacteria \\
\hline
\end{tabular}

sludge were only found as feeding synthetic wastewater, probably responsible for $\mathrm{P}$ removal. Tetrasphaera spp. (band 5), Chlorobaculum spp. (band 12) and Methylocystis spp. (band 13) were only detected within the DGGE patterns of feeding real domestic sewage. Tetrasphaera spp. was regarded as a PAO in wastewater treatment system (Kristiansen et al. 2013). It is probably that the corresponding organism of band 12, Chlorobaculum spp., is responsible for a sulfate reduction and was often found in secondary sedimentation tanks (Zhang et al. 2012). It was introduced into the BNR-IC system possibly from real domestic wastewater. In addition to, the band 2 corresponding to Rhodocyclus spp. is a typical DPAO capable of simultaneous nitrogen and phosphorus removal and was often found in biological enhanced phosphorus removal system (Huang et al. 2015; Lv et al. 2015; Zengin et al. 2011).

\section{Conclusions}

This study showed that effective nutrients removal and phosphorus recovery were achieved in the novel BNRIC process regardless of feeding types (synthetic or real domestic wastewater). The major phosphorus recovery mechanism was induced crystallization of HAP. When 
the BNR-IC system achieved the stable state, the COD, $\mathrm{NH}_{4}^{+}-\mathrm{N}, \mathrm{TN}$ and TP concentrations of effluent remained at a low level both for treating real domestic sewage and synthetic wastewater, meeting the discharge standard of municipal domestic sewage treatment (GB 18918-2012) formulated by Chinese government. Phosphorus recovery efficiency from synthetic wastewater was $70.2 \%$ slightly less than that from real domestic sewage (74.2\%). Importantly, phosphorus recovery effectively enhanced the subsequent biological phosphorus removal. It was found that an obvious shift in microbial community structure was observed by PCR-DGGE, and diversity of sludge using real domestic sewage was higher than that with synthetic wastewater. The results of this study suggest that the BNRIC operated in continuous flow is feasible for nutrients removal and phosphorus recovery from domestic sewage.

\section{Acknowledgements}

This research is supported by grant $1508085 \mathrm{ME} 90$ from Natural Science Foundation of Anhui Province, China and grant KJ2015A173 from Natural Science Foundation of the Ministry of Education of Anhui province, China.

\section{References}

Acelas, N. Y.; López, D. P.; Brilman, D. W.; Kersten, S. R.; Kootstra, A. M. J. 2014. Supercritical water gasification of sewage sludge: gas production and phosphorus recovery, Bioresource Technology 174: 167-175.

http://dx.doi.org/10.1016/j.biortech.2014.10.003

Boelee, N. C.; Temmink, H.; Janssen, M.; Buisman, C.; Wijffels, R. H. 2011. Nitrogen and phosphorus removal from municipal wastewater effluent using microalgal biofilms, Water Research 45(18): 5925-5933.

http://dx.doi.org/10.1016/j.watres.2011.08.044

Cusick, R. D.; Logan, B. E. 2012. Phosphate recovery as struvite within a single chamber microbial electrolysis cell, Bioresource Technology 107: 110-115.

http://dx.doi.org/10.1016/j.biortech.2011.12.038

GB 18918-2012. Discharge Standard of Pollutants for Municipal Wastewater Treatment Plant.

Gilbert, N. 2009. Environment: the disappearing nutrient, Nature News 461(7265): 716-718. http://dx.doi.org/10.1038/461716a

Guney, K.; Weidelener, A.; Krampe, J. 2008. Phosphorus recovery from digested sewage sludge as MAP by the help of metal ion separation, Water Research 42(18): 4692-4698. http://dx.doi.org/10.1016/j.watres.2008.08.016

Haiming, Z.; Xiwu, L.; Abualhail, S.; Jing, S.; Qian, G. 2014. Enrichment of PAO and DPAO responsible for phosphorus removal at low temperature, Environment Protection Engineering 40(1): 67-83.

Huang, W.; Li, B.; Zhang, C.; Zhang, Z.; Lei, Z.; Lu, B.; Zhou, B. 2015. Effect of algae growth on aerobic granulation and nutrients removal from synthetic wastewater by using sequencing batch reactors, Bioresource Technology 179: 187-192. http://dx.doi.org/10.1016/j.biortech.2014.12.024

Hutnik, N.; Kozik, A.; Mazienczuk, A.; Piotrowski, K.;
Wierzbowska, B.; Matynia, A. 2013. Phosphates (V) recovery from phosphorus mineral fertilizers industry wastewater by continuous struvite reaction crystallization process, Water Research 47(11): 3635-3643.

http://dx.doi.org/10.1016/j.watres.2013.04.026

Ichihashi, O.; Hirooka, K. 2012. Removal and recovery of phosphorus as struvite from swine wastewater using microbial fuel cell, Bioresource Technology 114: 303-307.

http://dx.doi.org/10.1016/j.biortech.2012.02.124

Kristiansen, R.; Nguyen, H. T. T.; Saunders, A. M.; Nielsen, J. L.; Wimmer, R.; Le, V. Q.; Mcllroy, S. J.; Petrovski, S.; Seviour, R. J.; Calteau, A. 2013. A metabolic model for members of the genus Tetrasphaera involved in enhanced biological phosphorus removal, The ISME Journal 7(3): 543-554. http://dx.doi.org/10.1038/ismej.2012.136

Lv, X.; Shao, M.; Li, J.; Li, C. 2015. Metagenomic analysis of the sludge microbial community in a lab-scale denitrifying phosphorus removal reactor, Applied Biochemistry and Biotechnology: 175(7): 3258-3270.

http://dx.doi.org/10.1007/s12010-015-1491-8

Moheimani, N. R.; Cord-Ruwisch, R.; Raes, E.; Borowitzka, M. A. 2013. Non-destructive oil extraction from Botryococcus braunii (Chlorophyta), Journal of Applied Phycology 25(6): 1653-1661. http://dx.doi.org/10.1007/s10811-013-0012-9

Ong, Y. H.; Chua, A.; Fukushima, T.; Ngoh, G. C.; Shoji, T.; Michinaka, A. 2014. High-temperature EBPR process: The performance, analysis of PAOs and GAOs and the fine-scale population study of Candidatus "Accumulibacter phosphatis", Water Research 64: 102-112.

http://dx.doi.org/10.1016/j.watres.2014.06.038

Qiu, G.; Ting, Y. 2014. Direct phosphorus recovery from municipal wastewater via osmotic membrane bioreactor (OMBR) for wastewater treatment, Bioresource Technology 170: 221229. http://dx.doi.org/10.1016/j.biortech.2014.07.103

Sengupta, S.; Pandit, A. 2011. Selective removal of phosphorus from wastewater combined with its recovery as a solid-phase fertilizer, Water Research 45(11): 3318-3330. http://dx.doi.org/10.1016/j.watres.2011.03.044

Seviour, R. J.; Mino, T.; Onuki, M. 2006. The microbiology of biological phosphorus removal in activated sludge systems, FEMS Microbiology Reviews 27(1): 99-127. http://dx.doi.org/10.1016/S0168-6445(03)00021-4

Shi, J.; Lu, X.; Yu, R.; Zhu, W. 2012. Nutrient removal and phosphorus recovery performances of a novel anaerobic-anoxic/ nitrifying/induced crystallization process, Bioresource Technology 121: 183-189.

http://dx.doi.org/10.1016/j.biortech.2012.06.064

Song, Y.; Dai, Y.; Hu, Q.; Yu, X.; Qian, F. 2014. Effects of three kinds of organic acids on phosphorus recovery by magnesium ammonium phosphate (MAP) crystallization from synthetic swine wastewater, Chemosphere 101: 41-48. http://dx.doi.org/10.1016/j.chemosphere.2013.11.019

Thai, P. K.; O’Brien, J.; Jiang, G.; Gernjak, W.; Yuan, Z.; Eaglesham, G.; Mueller, J. F. 2014. Degradability of creatinine under sewer conditions affects its potential to be used as biomarker in sewage epidemiology, Water Research 55: 272-279. http://dx.doi.org/10.1016/j.watres.2014.02.035

Westholm, L. J. 2006. Substrates for phosphorus removal-Potential benefits for on-site wastewater treatment?, Water Research 40(1): 23-36.

http://dx.doi.org/10.1016/j.watres.2005.11.006 
Yang, X.; Peng, Y.; Ren, N.; Guo, J.; Tang, X.; Song, J. 2013. Nutrient removal performance and microbial community structure in an EBPR system under the limited filamentous bulking state, Bioresource Technology 144: 86-93. http://dx.doi.org/10.1016/j.biortech.2013.06.103

Yetilmezsoy, K.; Sapci-Zengin, Z. 2009. Recovery of ammonium nitrogen from the effluent of UASB treating poultry manure wastewater by MAP precipitation as a slow release fertilizer, Journal of Hazardous Materials 166(1): 260-269. http://dx.doi.org/10.1016/j.jhazmat.2008.11.025

Yuan, Z.; Pratt, S.; Batstone, D. J. 2012. Phosphorus recovery from wastewater through microbial processes, Current Opinion in Biotechnology 23(6): 878-883. http://dx.doi.org/10.1016/j.copbio.2012.08.001

Zengin, G. E.; Artan, N.; Orhon, D.; Satoh, H.; Mino, T. 2011. Effect of aspartate and glutamate on the fate of enhanced biological phosphorus removal process and microbial community structure, Bioresource Technology 102(2): 894-903. http://dx.doi.org/10.1016/j.biortech.2010.09.023

Zhang, G.; Zhao, Q.; Jiao, Y.; Wang, K.; Lee, D.; Ren, N. 2012. Efficient electricity generation from sewage sludge usingbiocathode microbial fuel cell, Water Research 46(1): 43-52. http://dx.doi.org/10.1016/j.watres.2011.10.036

Zhang, H.; Fang, W.; Wang, Y.; Sheng, G.; Xia, C.; Zeng, R. J.; Yu, H. 2013. Species of phosphorus in the extracellular polymeric substances of EBPR sludge, Bioresource Technology 142: 714-718.

http://dx.doi.org/10.1016/j.biortech.2013.05.068

Zou, H.; Lu, X.; Li, T. 2014a. A novel process for nutrients removal and phosphorus recovery from domestic wastewater by combining BNR with induced crystallization, Journal of Environmental Engineering and Landscape Management 22(4): 274-283. http://dx.doi.org/10.3846/16486897.2014.931284

Zou, H.; Lu, X.; Saad, A. 2014b. Characterization of microorganisms responsible for phosphorus removal linking operation performance with microbial community structure at low temperature, Environmental Technology 35(9): 1101-1109. http://dx.doi.org/10.1080/09593330.2013.861858

Zou, H. M.; Lu, X. W.; Li, T. 2014c. Effect of side-stream phosphorus recovery on biological phosphorus removal performance investigated by chemical and microbial analyses in a novel BNR-IC process, Water Science \& Technology 70(9): 1441-1447. http://dx.doi.org/10.2166/wst.2014.351

Haiming ZOU. Dr, Associate Professor, Department of Resource and Environment, Anhui Science and Technology University; School of Energy and Environment, Southeast University. Research interests: with nitrogen and phosphorus removal from domestic wastewater.

Xiwu LU. Dr, Professor, School of Energy and Environment, Southeast University. Research interests: research on nitrogen and phosphorus removal from wastewater. 